\title{
Review Article \\ Predicting Surface Runoff from Catchment to Large Region
}

\author{
Hongxia Li, ${ }^{1}$ Yongqiang Zhang, ${ }^{2}$ and Xinyao Zhou ${ }^{3}$ \\ ${ }^{1}$ State Key Laboratory of Hydraulics and Mountain River Engineering, Sichuan University, Chengdu 610065, China \\ ${ }^{2}$ CSIRO Land Water Flagship, Clunies Ross Street, Acton, Canberra, ACT 2601, Australia \\ ${ }^{3}$ Key Laboratory of Agricultural Water Resources, Center for Agricultural Resources Research, Chinese Academy of Sciences, \\ Shijiazhuang 050021, China
}

Correspondence should be addressed to Yongqiang Zhang; yongqiang.zhang@csiro.au

Received 5 January 2015; Accepted 7 June 2015

Academic Editor: Enrico Ferrero

Copyright (c) 2015 Hongxia Li et al. This is an open access article distributed under the Creative Commons Attribution License, which permits unrestricted use, distribution, and reproduction in any medium, provided the original work is properly cited.

Predicting surface runoff from catchment to large region is a fundamental and challenging task in hydrology. This paper presents a comprehensive review for various studies conducted for improving runoff predictions from catchment to large region in the last several decades. This review summarizes the well-established methods and discusses some promising approaches from the following four research fields: (1) modeling catchment, regional and global runoff using lumped conceptual rainfall-runoff models, distributed hydrological models, and land surface models, (2) parameterizing hydrological models in ungauged catchments, (3) improving hydrological model structure, and (4) using new remote sensing precipitation data.

\section{Introduction}

Runoff from land surface is the flow of water that comes from excess water from rain, meltwater, or other sources that flow over the Earth's surface. It is a major component in regional and global hydrological cycle. It has direct impacts on human lives since it is a key water resource for agriculture, industry, urban water use, and so forth. It is crucial to understand complex relationships between rainfall and runoff processes and then to accurately estimate surface runoff for efficient design, planning, and management of catchments. This can be achieved using hydrological modeling that not only estimates continuous surface runoff, but also helps in understanding catchment behaviors and modeling impacts of climate and land use changes on surface water balance $[1,2]$.

Model calibration is a necessary step for achieving good simulations and predictions of surface runoff. Hydrological models are usually calibrated against observed streamflow to tune their model parameters to account for the inputs and water fluxes in a catchment $[3,4]$. With the development of remote sensing technology, more information is now available for hydrological modeling, for example, using remote sensing precipitation and leaf area index as model inputs $[5,6]$, and incorporating more data (such as remote sensing soil moisture, evapotranspiration, groundwater, and snow cover area) for multiple objective model calibration $[4,7-9]$.

Local hydrological models have been largely used to predict runoff time series using a small number of catchments that covers a small region where climate conditions are similar $[10,11]$. Recently, they were used to predict surface runoff in ungauged catchments in a large region, such as in southeastern Australia [12], the Tibetan Plateau [13], UK [14], and France [15]. This is important since lots of rivers and their reaches and tributaries in the world are ungauged or poorly gauged [14, 16, 17].

It is a hard task to have a credible prediction of surface runoff in ungauged catchments or regions where no runoff data are available or runoff data are available sparsely. Hydrologists have been attempting to develop strategies to estimate runoff on ungauged catchments since the 1970s, especially after the International Association of Hydrological Sciences (IAHS) launched an initiative Predictions in Ungauged Basins (PUB) in 2003, which aims at predicting or forecasting the hydrological responses in ungauged or poorly gauged 
basins and their associated uncertainty [17]. Since then, many approaches have been developed for estimating surface runoff in ungauged basins [18], such as regionalization $[15,19,20]$, and regional calibration against observations from multiple catchments [21, 22].

Predicting surface runoff using catchment, regional and global runoff models has achieved numerous outcomes, but there are still lots of issues that lead to unsatisfactory performances. This paper presents a comprehensive review of predicting surface runoff from catchments to large regions, which is a fundamental and challenging task in hydrology. This includes review and discussions in (1) hydrological models, (2) parameterization, (3) improvement of hydrological model structure, and (4) use of new forcing data.

\section{Catchment, Regional and Global Runoff Models}

There exist various models to simulate surface runoff in an empirical, semimechanistic or fully mechanistic way. Generally, surface runoff models are classified from deterministic to stochastic models, from physically based (white-box) to black-box or empirical and to conceptual models, from lumped to distributed models, and from global hydrological to land surface models (LSMs) [39, 73-75]. This paper separates the hydrological models into three categories according to complexity and application, including (1) lumped conceptual rainfall-runoff (RR) models, (2) distributed hydrological models, and (3) global hydrological/LSMs $[73,76]$. The first two categories of the hydrological models are normally applied from catchments to regions and the third category of the hydrological models is generally applied from a large region to the global land surface. Table 1 summarizes the three categories of major hydrological models for runoff estimations/predictions across a wide range of climate and physiographic conditions.

\subsection{Lumped Conceptual Rainfall-Runoff Models. Lumped} conceptual RR models treat a catchment as a single homogeneous unit, and they are widely used since such models tend to be parametrically parsimonious while yielding good model performance after calibration using historical watershed input-output data [77].

Numerous RR models have been developed and documented $[78,79]$. Crawford and Linsley's Stanford Watershed Model was one of the notably successful efforts in introducing a complex RR model accounting for the dynamics of hydrologic processes governing in a watershed [32]. Other examples of conceptual RR models include Xinanjiang model developed in China in the 1980s [34] and Sacramento Soil Moisture Accounting Model (SAC-SMA) [30], widely used operational model in the US National Weather Service (NWS) for flood forecasting.

RR models have been used very successfully to estimate runoff at small and large catchments under different climate regimes. Usually, RR models use rainfall and other climate data (e.g., temperature and/or potential evaporation) to estimate runoff. Although the main emphasis of $\mathrm{RR}$
TABLE 1: Major catchment, regional and global runoff models.

\begin{tabular}{|c|c|c|c|}
\hline Model type & Model & Country & Reference \\
\hline \multirow{13}{*}{ Lumped model } & AWBM & Australia & [23] \\
\hline & GR4J & Australia & [24] \\
\hline & $\mathrm{HBV}$ & Sweden & [25] \\
\hline & HEC & USA & [26] \\
\hline & HSPF & USA & [27] \\
\hline & HYDROLOG & Australia & [28] \\
\hline & IHACRES & Australia & [29] \\
\hline & Sacramento & USA & [30] \\
\hline & SIMHYD & Australia & {$[31]$} \\
\hline & SWM & USA & {$[32]$} \\
\hline & Tank & Japan & [33] \\
\hline & Xinanjiang & China & [34] \\
\hline & SRM & Nordic & [35] \\
\hline \multirow{10}{*}{ Physical model } & CEQUEAU & Canada & {$[36]$} \\
\hline & HYDROTEL & USA & [37] \\
\hline & IHDM & USA & [38] \\
\hline & MIKE-SHE & Denmark & [39] \\
\hline & SHE & Denmark & {$[40]$} \\
\hline & SLURP & UK & {$[41]$} \\
\hline & SWAT & USA & {$[42]$} \\
\hline & SWMM & USA & [43] \\
\hline & TOPMODEL & UK & {$[44]$} \\
\hline & WATELOOD & Canada & [45] \\
\hline \multirow{28}{*}{$\begin{array}{l}\text { Global } \\
\text { hydrological/land } \\
\text { surface model }\end{array}$} & BUCKET & Japan & {$[46]$} \\
\hline & CABLE & Australia & [47] \\
\hline & BATS & USA & [48] \\
\hline & CLM & USA & [49] \\
\hline & CLMTOP & USA & [50] \\
\hline & COLASSiB & USA & {$[51]$} \\
\hline & GWAVA & USA & {$[52]$} \\
\hline & H08 & USA & {$[53]$} \\
\hline & HTESSEL & USA & {$[54]$} \\
\hline & HYSSiB & USA & [55] \\
\hline & ISBA & France & [56] \\
\hline & JULES & UK & [57] \\
\hline & $\mathrm{LaD}$ & USA & {$[58]$} \\
\hline & LPJmL & USA & [59] \\
\hline & MacPDM & USA & [60] \\
\hline & MATSIRO & USA & {$[61]$} \\
\hline & Mosaic & USA & {$[62]$} \\
\hline & MOSES2 & UK & [57] \\
\hline & MPI-HM & USA & {$[63]$} \\
\hline & Noah & USA & {$[64]$} \\
\hline & NSIPP & USA & [65] \\
\hline & Orchidee & USA & {$[66]$} \\
\hline & SiBUC & Japan & [67] \\
\hline & SWAP & Russia & {$[68]$} \\
\hline & $\mathrm{SiB}$ & USA & [69] \\
\hline & VIC & USA & [70] \\
\hline & VISA & USA & {$[71]$} \\
\hline & WaterGAP & USA & {$[72]$} \\
\hline
\end{tabular}

models is to estimate runoff, they are normally designed to simulate actual evapotranspiration to account for soil 
water balance. However, they have no direct interest in quantifying surface energy fluxes [76]. The parameters in the RR models are usually optimized such that the runoff simulated matches as closely as possible the recorded runoff. A variety of model calibration techniques (including manual calibration and automatic calibration techniques) have been developed and implemented to ensure conformity between the model simulations of system behavior and observations $[3,80]$.

Compared to the distributed hydrological models, the RR models are simpler and need less input data, and the calibration cost is cheap, so they are quite easy to be used and are important tools for hydrologic analysis. More importantly, the RR models are comparable to the distributed hydrological models, in terms of model accuracy for predicting daily, monthly, and annual runoff time series. For instance, Vansteenkiste et al. [81] compared three RR models (NAM, PDM, and VHM) to two distributed models (WetSpa and MIKE-SHE) in a medium sized catchment in Belgium to assess the model accuracy. They found that all tested models perform well for estimating total runoff and their components, peak and low flow extremes. However, calibrating the RR models is much less time consuming and produced higher overall model performance in comparison to the two distributed models. Reed et al. [82] compared 12 distributed models with a lumped model, and the results show that the lumped model outperformed distributed models in more cases, while some calibrated distributed models can perform at a level comparable to or better than a calibrated lumped model. The limit of the RR models is that they cannot simulate the spatial pattern change in land cover and land use influencing surface water availability.

The RR models are normally applied at catchment scales. Hydrologic prediction of the RR models is highly influenced by the uncertainties in the forcing data (generally taken as deterministic), observed system response (due to errors in measuring the physical quantities), imperfection of the model structure, and the parameter values resulting from the model calibration which is profoundly affected by uncertainty sources [3].

In summary, the RR models are still very important tools in hydrological modeling, particularly for predicting runoff in ungauged catchments because of their simplicity and usability.

2.2. Distributed Hydrological Models. Distributed hydrological models make a series of hydrological processes interconnected, such as runoff generation, recharge to groundwater, snow accumulation and melt, soil moisture dynamics, evapotranspiration, and routing in lakes and rivers [10]. In addition, distributed hydrological models take account of the spatial variability of climate, terrain, soil, and vegetation. These elements are divided in smaller units that are more homogenous than the whole watershed. Therefore, this feature offers the potential to improve hydrologic predictions [83]. The distributed hydrological model can be directly used for estimating land use and land cover change impact on surface runoff and water availability $[1,2]$. This is particularly important for catchments with a wide range of climatic and land surface conditions.

The distributed hydrological models have been well developed since the 1970s because of the robust development of 3S (RS/GPS/GIS) technology. A representative semidistributed hydrological model is the topography-based hydrological model named as TOPMODEL that was developed in 1979. It describes runoff generation process including both saturation excess and infiltration excess runoff according to topographic index derived from digital elevation model (DEM) [44]. The spatial variability of precipitation, however, is not considered by TOPMODEL. After TOPMODEL, distributed hydrological models such as SHE (System Hydrologic European) [40] and SWAT (Soil and Water Assessment Tool) [42] are fully distributed and contain more complex hydrological processes.

Although the distributed hydrological models have more solid physical base compared to the lumped models, several model comparison studies [74, 75, 82, 84, 85] have shown that no single model performs consistently best but rather that individual model performances vary with the setting. So selecting models depends on objectives, application, and availability of data.

Despite their complexity, the distributed hydrological models are very useful for investigating changes in hydrological processes caused by anthropogenic activities, such as forestation, deforestation, and urbanization.

2.3. Global Hydrological and Land Surface Models. The hydrological models presented in Sections 2.1 and 2.2 are normally applied to a catchment to regional scale. At a larger scale from a large region to globe, global hydrological and LSMs (Table 1) are developed for simulating/predicting surface runoff. It is noted that global hydrological models are traditionally focused on water resources and lateral water fluxes while LSMs can be coupled to global climate models, to describe the vertical exchange of heat, water, carbon, or other elements. Based on the spatial application, this review paper does not separate the two kinds of models, naming them "global LSMs" on a whole.

Compared to the lumped RR and distributed hydrological models, the global LSMs are far more complicated since they can simulate not only hydrological processes, but also various material and energy transfer processes on land surface [86]. These processes include precipitation interception, snow accumulation and melt, runoff generation, water transfer amongst soil layers, shortwave radiation's reflection and transmission, longwave radiation's absorption and emission, separation of sensible heat and latent heat, plant growth and respiration, photosynthesis and gross primary production, microbe activities, and nutrient cycle.

The first-generation LSMs such as Bucket model [87] do not consider vegetation and include only one soil layer. The second-generation LSMs such as BATS [48] and SiB [69] contain "big-leaf" vegetation and 2-3 soil layers. The third-generation LSMs such as CLM [49] contain "twoleaf" vegetation and multilayer soil layer for hydrological 
processes. Some widely used land surface models are listed in Table 1.

Surface runoff process is considered quite differently between distributed hydrological models and global land surface models. Surface runoff is a key output in lumped $\mathrm{RR}$ and distributed hydrological models, while it is taken as residue of water balance equation in global LSMs. Because of the accumulated errors built in land surface models, they perform generally more poorly than distributed hydrological models [88-90]. Gosling et al. [91] compared the projected impacts of climate change on river runoff from two types of distributed hydrological models, a global hydrological model (GHM) and catchment-scale hydrological models (CHMs). Results show that there are differences between GHMs and CHMs in mean annual runoff due to differences in potential evapotranspiration estimation methods, and the differences in projected changes of mean annual runoff between the two types of hydrological model can be substantial for a given GCM. Haddeland et al. [74] compared six land surface models and five global hydrological models and results show that significant simulation differences between models are found to be caused by the snow scheme employed, and differences between models are a major source of uncertainty.

The main strength of global hydrological and land surface models is that they can be used for answering the regional and global questions for water availability and changes in global hydrological cycles [74].

\section{Parameterization of Hydrological Models in Ungauged Catchments}

3.1. Regionalization. There are no observations or lack of observations in ungauged catchments. Therefore to predict surface runoff in the ungauged catchments depends on alternative prediction methods [17]. Regionalization is a commonly used method for runoff predictions $[15,92]$, in which model parameters calibrated from gauged catchments are transferred to ungauged catchments using various approaches. It is a challenge to get satisfactory regionalization results $[15,17,93,94]$ because of limit of dataset, a wide range of catchment attributes, poor quality of model inputs, unsatisfactory model calibrations, and so on $[15,17]$.

The regionalization is mainly conducted with hydrological models, although it can be achieved using modelindependent methods (e.g., Artificial Neural Network) [20, 95]. The popular regionalization approaches that extrapolate hydrologic model parameters to estimate streamflow at ungauged catchments can be grouped into (a) arithmetic mean method (AM) [15, 19]; (b) spatial proximity approach (SP) (spatial distance) $[96,97]$; (c) physical similarity approach (PS) [93, 98, 99]; (d) regression method (Reg) [14]; and (e) hydrological similarity approach (HS) [100].

All these regionalization methods have been applied in many catchments, and many attempts have been made to determine which regionalization approach was the most appropriate (Table 2). Merz and Blöschl [19] tried to regionalize an 11-parameter semidistributed conceptual RR model based on more than 300 Austrian catchments. It shows that spatial proximity performs best, and using nested catchments as donors may significantly improve performance of spatial proximity. Young [14] tried to regionalize a six-parameter version of the PDM model on 260 UK catchments and found that regression approach yielded the best results, compared to other approaches. Oudin et al. [15] compared three regionalization schemes (SP, PS, and Reg) based on 913 French catchments using two lumped models and found that spatial proximity provides the best regionalization solution. Li et al. [101] proposed a new regionalization method (the index model), which establishes a nonparametric relationship between each parameter of predictive tools and a linear combination of predicators. The prediction results of 227 catchments in southeast Australia show that the index model produces the most accurate prediction compared to regional models based on the linear regression, nearest neighbor, and hydrological similarity. Shu and Ouarda [102] introduced a regression-based logarithmic interpolation method to estimate regional FDCs at ungauged sites, and the estimated FDC is combined with a spatial interpolation algorithm to obtain daily streamflow estimates. McIntyre et al. [103] and Oudin et al. [15] showed that output averaging (the target catchment is modeled using parameter values from many donor catchments) can reduce uncertainty in runoff predictions in ungauged catchments. Similarly, Reichl et al. [98] showed that flow prediction using an optimized model averaging method (based on physical similarities) is superior to regression and spatial proximity approaches.

In summary, the studies carried out in most countries, such as Austria, France, and Australia, found that SP is better than PS and Reg is the least satisfactory. This is also confirmed in the highest plateau, the Tibetan Plateau [105]. Only in UK did the studies find that Reg performs better than SP or PS.

There are various reasons explaining the different model performance between the abovementioned studies, including using different catchment sets, different catchment descriptors, and different hydrological models $[14,15]$. This suggests that each regionalization approach does not always perform consistently. Razavi and Coulibaly [20] found that the performance of regionalization approaches is climate related, and overall spatial proximity and physical similarity have shown satisfactory performance in arid to warm temperate climates (e.g., Australia) and regression-based methods have been preferred in warm temperate regions (e.g., most European countries). To fully understand the performance of the various regionalization approaches, it is critical to have global comparison studies. However, such studies have not been reported yet.

3.2. Multiple Objective Model Calibration. It was recognized early $[80,107]$ that models calibrated only to observed hydrographs can be considered overparameterized if they consist of more than five parameters [29], because the predictive capability of hydrological models would be limited by high model complexity relative to the typically low number of model constraints used to calibrate the models 
TABLE 2: Summary of regionalization approaches conducted using large datasets.

\begin{tabular}{|c|c|c|c|c|}
\hline Method & Comparing & Model & Region/country & References \\
\hline $\begin{array}{l}\text { AM } \\
\text { Reg }\end{array}$ & $\begin{array}{l}\text { Average of nested neighbors is better than Reg (global } \\
\text { or regional) }\end{array}$ & $\mathrm{HBV}$ & 308 catchments in Austria & {$[19]$} \\
\hline $\begin{array}{l}\text { PS } \\
\text { Reg }\end{array}$ & Output averaging based on PS is better than Reg & PDM & 127 catchments in UK & {$[103]$} \\
\hline $\begin{array}{l}\text { AM } \\
\text { SP } \\
\text { PS } \\
\text { Reg }\end{array}$ & $\begin{array}{l}\text { SP (Kriging) and PS perform best; all regionalization } \\
\text { methods perform similarly in simulating snow cover }\end{array}$ & $\mathrm{HBV}$ & 320 catchments in Austria & {$[96]$} \\
\hline $\begin{array}{l}\text { PS } \\
\text { Reg }\end{array}$ & $\begin{array}{l}\text { For PDM, PS performs slightly better than the Reg, } \\
\text { whereas for TATE Reg performs best }\end{array}$ & $\begin{array}{l}\text { PDM } \\
\text { TATE }\end{array}$ & 119 catchments in the UK & {$[104]$} \\
\hline $\begin{array}{l}\text { Reg } \\
\text { PS }\end{array}$ & $\begin{array}{l}\text { The regression-based approach is better than the } \\
\text { nearest neighbor based approach }\end{array}$ & PDM & 260 catchments in UK & {$[14]$} \\
\hline $\begin{array}{l}\text { SP } \\
\text { PS } \\
\text { Reg }\end{array}$ & $\begin{array}{l}\text { SP is the best, Reg is the least satisfactory, and PS is } \\
\text { intermediary }\end{array}$ & $\begin{array}{l}\text { GR4J, } \\
\text { TOPMO }\end{array}$ & 913 catchments in France & {$[15]$} \\
\hline $\begin{array}{l}\text { SP } \\
\text { PS }\end{array}$ & SP is better than PS & Xinanjiang & $\begin{array}{l}210 \text { catchments in southeast } \\
\text { Australia }\end{array}$ & {$[97]$} \\
\hline $\begin{array}{l}\text { SP } \\
\text { PS } \\
\text { Reg }\end{array}$ & $\begin{array}{l}\text { An optimized averaging method (based on PS) is } \\
\text { superior to Reg and SP approaches }\end{array}$ & SIMHYD & 184 catchments in Australia & {$[98]$} \\
\hline $\begin{array}{l}\text { SP } \\
\text { PS }\end{array}$ & $\begin{array}{l}\text { SP performs slightly better than PS and the integrated } \\
\text { similarity approach performs only very marginally } \\
\text { better than SP }\end{array}$ & $\begin{array}{l}\text { Xinanjiang } \\
\text { SIMHYD }\end{array}$ & $\begin{array}{l}210 \text { catchments in southeast } \\
\text { Australia }\end{array}$ & {$[12]$} \\
\hline $\begin{array}{l}\text { SP } \\
\text { PS } \\
\text { Reg } \\
\text { HS }\end{array}$ & $\begin{array}{l}\text { The index model that establishes relationships between } \\
\text { hydrological signatures and catchment attributes is the } \\
\text { best, followed by Reg, HS, and SP }\end{array}$ & $\begin{array}{l}\text { Three- } \\
\text { parameter } \\
\text { FDC }\end{array}$ & $\begin{array}{l}227 \text { catchments in southeast } \\
\text { Australia }\end{array}$ & {$[101]$} \\
\hline HS & $\begin{array}{l}\text { HS based on FDC produces better runoff simulation } \\
\text { compared to the others (drainage area and spatial } \\
\text { proximity) }\end{array}$ & $\mathrm{HBV}$ & $\begin{array}{l}\text { Karkheh river basin, western part } \\
\text { of Iran }\end{array}$ & {$[100]$} \\
\hline $\begin{array}{l}\text { SP } \\
\text { PS } \\
\text { Reg }\end{array}$ & $\begin{array}{l}\text { An approach coupling the SP (IDW) and the PS is } \\
\text { better than SP, PS, and Reg }\end{array}$ & MAC-HBV & $\begin{array}{l}\text { The main watersheds across the } \\
\text { province of Ontario }\end{array}$ & {$[93]$} \\
\hline $\begin{array}{l}\text { SP } \\
\text { PS }\end{array}$ & SP is better than PS & $\begin{array}{l}\text { SIMHYD and } \\
\text { GR4J }\end{array}$ & $\begin{array}{l}8 \text { catchments in the southeastern } \\
\text { Tibetan Plateau }\end{array}$ & {$[105]$} \\
\hline $\begin{array}{l}\text { SP } \\
\text { Reg }\end{array}$ & $\begin{array}{l}\text { An index model that establishes relationships between } \\
\text { hydrological signatures and catchment attributes is } \\
\text { better than SP for getting salient flow characteristics }\end{array}$ & $\begin{array}{l}\text { An index model } \\
\text { and GR4J }\end{array}$ & $\begin{array}{l}228 \text { catchments in southeast } \\
\text { Australia }\end{array}$ & {$[106]$} \\
\hline
\end{tabular}

AM: arithmetic mean method; SP: spatial proximity method; PS: physical similarity method; Reg: regression methods; HS: hydrological similarity method.

[108]. An important strategy to overcome this problem was the incorporation of more information (such as different aspects of the hydrograph, soil moisture, evapotranspiration, groundwater, and snow depth) for multiple objective model calibration.

Madsen [7] used a calibration scheme including optimization of multiple objectives that measure different aspects of the hydrograph (overall water balance, overall shape of the hydrograph, peak flows, and low flows). Seibert and McDonnell [109] reported that the inclusion of groundwater dynamics results in significantly improved and more consistent overall model performances. Nester et al. [110] demonstrated the value of remotely sensed snow cover patterns to constrain parameter uncertainty of catchment models.
Others used remotely sensed soil moisture and evaporation, respectively, to improve model parameterizations [111-113]. Zhang et al. [114] showed that the incorporation of remotely sensed leaf area index and surface soil moisture measurements into the calibration objective function marginally improves the daily runoff estimates but noticeably improves the leaf area index and soil moisture estimates in the validation catchments. Zhang et al. [4] used remotely sensed evapotranspiration estimates together with recorded streamflow to constrain rainfall-runoff model calibration and then used optimized parameter sets for runoff predictions. They found that the use of remotely sensed evapotranspiration data in calibration leads to improved daily or monthly runoff predictions in ungauged catchments. However, Willem Vervoort et 
al. [9] show that satellite evapotranspiration did not improve the calibration results of the lumped conceptual model and confirm that the calibration of models using multiple environmental time series (such as MODIS evapotranspiration and streamflow) can be used to identify structural model issues.

3.3. Regional Calibration against Observations from Multiple Catchments. Regional model calibration is defined here as model calibration simultaneously against observations in multiple catchments (from dozens to hundreds) across a wide region to obtain a single parameter set for all catchments. In contrast, local model calibration is referred to as the calibration against observations in a single catchment.

The major advantage of the local model calibration is that an optimum parameter set can be obtained for each individual catchment and will match the local data most accurately. However, the locally optimized parameter values are not always suitable for runoff predictions because gauging stations can be few and far apart, resulting in that the underlying assumption that nearby catchments have similar responses can be problematic. Furthermore, observational errors (e.g., in streamflow gauging and rainfall inputs) can cause the local calibration to be biased, with biased model parameters being regionalized.

The main benefit of regional model calibration is that (1) use of one set of optimized parameter values (or perhaps several sets if different objective functions are considered or if a research region is divided into different subregions) can improve hydrological and vegetation estimates at the regional scale and (2) there is no noticeable degradation from model calibration to model validation. The disadvantage of regional calibration is that it requires lots of computation resources and it is normally conducted using super computer clusters.

Previous studies showed that regional calibration could improve the accuracy of simulated runoff in ungauged regions and has been used in runoff simulation and prediction $[21,115]$. Regional calibration would be an important research field of large-scale hydrological simulation and predictions and will be strengthened with the computational development.

\section{Improving Hydrological Model Structure}

The model structure represents a formalized perception of how the catchment system is organized and how the various parts are interconnected [138]. Selection of a suitable model structure ideally depends on a number of factors as one strives to represent the runoff processes in a realistic way, so that the model can be safely used in a predictive mode. However, there is still some room for further improving model structures.

4.1. Modifying RR Model Structure. Usually, RR models use simply conceptual equations to simulate evapotranspiration based on soil wetness and potential evapotranspiration (calculated from basic climate data) and seldom consider vegetation dynamics, which can play an important role in midlatitude catchments $[11,139,140]$. Because of lack of surface vegetation information in RR modeling inputs, calibrated RR models may not estimate water balance components, evapotranspiration, and water storage change accurately, which possibly limits their ability to estimate runoff.

Remotely sensed data can provide temporally dynamic and spatially explicit information on land surface characteristics such as vegetation cover types and leaf area index. Vegetation processes play an important role in evapotranspiration and runoff in midlatitude catchments [140, 141]. Yildiz and Barros [140] showed that vegetation properties such as fractional vegetation coverage and leaf area index (LAI) had significant effects on hydrological model results via control of evapotranspiration rates, and this control was especially critical during the spring-summer transition which coincided with the greening season in midlatitudes.

A suitable way to integrate vegetation process data into hydrological models is to use remote sensing vegetation data, such as LAI and fractional vegetation cover [142144]. Recent studies have tried to include remote sensing vegetation information as inputs into RR models. Reference [97] used MODIS LAI data combined with the PenmanMonteith equation in the lumped Xinanjiang model, and results showed that it can improve the prediction of runoff in ungauged basin. Oudin et al. [145] modified the water balance models to introduce the fractional coverage of land cover types and results showed that land cover information improves the overall model efficiency.

\subsection{Improving Distributed Hydrological, Land Surface Model} Structure. Appropriate land surface parameterization is based on comprehensive understanding to land surface processes and thus could improve performance of physically based models. For instance, Liang and Xie [146] used a new surface runoff parameterization which takes into account effects of soil heterogeneity on Horton and Dunne runoff to replace the old parameterization in VIC model. Results showed that the new parameterization plays a very important role in partitioning the water budget between surface runoff and soil moisture. Pitman et al. [147] compared the accuracy of estimated runoff in the region that ranged from $30 \mathrm{~N}$ to $90 \mathrm{~N}$ by BASE model with and without frozen soil parameterization. Results proved that frozen soil parameterization greatly influenced runoff generation with less runoff variability. Haverd and Cuntz [148] found that soil litter is important for simulation of soil moisture and evapotranspiration in forest region. When coupled with a soil litter model, the accuracy of CABLE has been greatly improved for estimating soil moisture and evapotranspiration in a forest flux site in Australia. Choi and Liang [149] detected several deficiencies in the existing formulations for terrestrial hydrologic processes in CLM and improved model performance for predicting runoff by five modifications of its parameterization. In summary, there is plenty of room 
TABLE 3: Summary of precipitation datasets.

\begin{tabular}{|c|c|c|c|c|c|c|}
\hline Name & Source & Domain & Period of record & $\begin{array}{c}\text { Available } \\
\text { timestep(s) }\end{array}$ & Available resolution & References \\
\hline APHRODITE & $\begin{array}{l}\text { U. of Tsukuba and } \\
\text { JMA }\end{array}$ & Asia & 1951-2007 & Daily & $\begin{array}{c}0.25 \times 0.25,0.5 \times 0.5 \\
0.05 \times 0.05 \text { (Japan } \\
\text { only) }\end{array}$ & {$[116]$} \\
\hline CHOMPS & CICS & Global & $1998-2007$ & Daily & $0.25 \times 0.25$ & {$[117]$} \\
\hline GSWP-2 & GEWEX & Global & 1986-1995 & Subdaily & $1 \times 1$ & [118] \\
\hline WFD & EU-FP6 & Global & 1901-2001 & Subdaily & $0.5 \times 0.5$ & [119] \\
\hline WFDEI & EU-FP6 & Global & 1979-2012 & Subdaily, daily & $0.5 \times 0.5$ & {$[120]$} \\
\hline CMAP & NOAA CPC & Global & 1979-2011 & Monthly, pentad & $2.5 \times 2.5$ & {$[121]$} \\
\hline CMORPH & $\mathrm{CPC}$ & Global & $2002-2013$ & Subdaily, daily & $0.25 \times 0.25$ & {$[122]$} \\
\hline CRU & CRU & Global & 1901-2013 & Monthly & $0.5 \times 0.5$ & [123] \\
\hline Daymet & U. of Montana & North America & 1980-2013 & Daily & $1 \mathrm{~km} \times 1 \mathrm{~km}$ & {$[124]$} \\
\hline $\begin{array}{l}\text { Global (land) } \\
\text { precipitation and } \\
\text { temperature }\end{array}$ & U. of Delaware & Global & $1900-2010$ & Monthly & $0.5 \times 0.5$ & {$[125]$} \\
\hline GPCC & DWD & Global & $1900-2010$ & Monthly & $\begin{array}{c}0.5 \times 0.5,1 \times 1 \\
2.5 \times 2.5\end{array}$ & {$[126]$} \\
\hline Princeton & Princeton University & Global & 1948-2008 & Subdaily & $1 \times 1$ & {$[127]$} \\
\hline GPCP & GSFC (NASA) & Global & 1979-2014 & Monthly & $2.5 \times 2.5$ & {$[128]$} \\
\hline HOAPS & $\begin{array}{l}\text { CM SAF and Uni. of } \\
\text { Hamburg }\end{array}$ & Global & 1987-2008 & $\begin{array}{l}\text { Subdaily, } \\
\text { monthly }\end{array}$ & $0.5 \times 0.5$ & [129] \\
\hline COREV2 & NCAR & Global & 1949-2006 & $\begin{array}{l}\text { Subdaily, daily, } \\
\text { monthly }\end{array}$ & $1 \times 1$ & {$[130]$} \\
\hline NLDAS & $\begin{array}{l}\text { NASA, NOAA, } \\
\text { Princeton, U. of } \\
\text { Washington }\end{array}$ & North America & $1979-2014$ & Hourly & $0.125 \times 0.125$ & {$[131]$} \\
\hline GLDAS & NASA, NOAA & Global & $1948-2014$ & $\begin{array}{l}\text { Subdaily, } \\
\text { monthly }\end{array}$ & $0.25 \times 0.25,1 \times 1$ & {$[132]$} \\
\hline PERSIANN & CHRS & Global & $1979-2014$ & $\begin{array}{l}\text { Subdaily, } \\
\text { monthly }\end{array}$ & $0.25 \times 0.25$ & {$[133]$} \\
\hline $\mathrm{PREC} / \mathrm{L}$ & NOAA & Global & $1948-2014$ & Monthly & $\begin{array}{c}2.5 \times 2.5,1 \times 1 \\
0.5 \times 0.5\end{array}$ & {$[134]$} \\
\hline PRISM & $\begin{array}{l}\text { Oregon State } \\
\text { University }\end{array}$ & North America & $1895-2014$ & Daily, monthly & $4 \mathrm{~km}, 800 \mathrm{~m}$ & {$[135]$} \\
\hline SSM/I, SSMIS & NASA & Global & 1987-2012 & $\begin{array}{l}\text { Daily, monthly, } \\
\text { weekly }\end{array}$ & $0.25 \times 0.25$ & {$[136]$} \\
\hline TRMM & NASA and JAXA & Tropics & $1998-2014$ & $\begin{array}{c}\text { Subdaily, daily, } \\
\text { monthly }\end{array}$ & $0.25 \times 0.25$ & {$[137]$} \\
\hline
\end{tabular}

APHRODITE: Asian Precipitation-Highly Resolved Observational Data Integration Towards Evaluation of Water Resources; JMA: Japan Meteorological Agency; CHOMPS: CICS High-Resolution Optimally Interpolated Microwave Precipitation from Satellites; CICS: Cooperative Institute for Climate Studies; GSWP: Global Soil Wetness Project; GEWEX: Global Energy and Water Cycle Experiment; NASA: National Aeronautics and Space Administration; NOAA: National Oceanic and Atmospheric Administration; WFD: WATCH Forcing Data; EU-FP6: European Union Sixth Framework Programme; WFDEI: WATCH Forcing Data methodology applied to ERA-Interim reanalysis data; CMAP: CPC Merged Analysis of Precipitation; CPC: Climate Prediction Center; CMORPH: CPC MORPHing technique high resolution precipitation (60S-60N); CRU: Climatic Research Unit; Daymet: Daily Surface Weather and Climatological Summaries; GPCC: Global Precipitation Climatology Centre; DWD: German Weather Service; GPCP: Global Precipitation Climatology Project; HOAPS: Hamburg Ocean Atmosphere Parameters and Fluxes from Satellite Data; CM SAF: Satellite Application Facility on Climate Monitoring; COREV2: Common Ocean Reference Experiment Version 2: Large-Yeager Air-Sea Surface Flux; NCAR: National Center for Atmospheric Research; NLDAS: North American Land Data Assimilation System; GLDAS: Global Land Data Assimilation System; PERSIANN: Precipitation Estimation from Remotely Sensed Information using Artificial Neural Networks; CHRS: Center for Hydrometeorology and Remote Sensing; PRISM: Parameter-Elevation Relationships on Independent Slopes Model; PREC/L: NOAA's Precipitation Reconstruction Land; SSM/I, SSMIS: Special Sensor Microwave/Imager and Sounder; TRMM: Tropical Rainfall Measuring Mission; JAXA: Japan Aerospace Exploration Agency. 
to improve global land surface model structure for better estimation of runoff from large region to global land surface.

\section{Improving Precipitation Inputs}

High quality daily precipitation estimates are required for accurate hydrological modeling. There are two major sources to estimate precipitation fields: rain gauge stations and remote sensing devices (such as satellites and radar). The observations obtained from rain gauges are considered to be more accurate and reliable, but the spatial coverage is unsatisfactory. Hence, the areal precipitation estimates constructed solely by rain gauges exhibit a great deal of uncertainty especially in the areas of low rain gauge density. Remote sensing gridded precipitation estimates are presented in a good coverage in space/time and with less uncertainty $[150,151]$. However, the coverage of weather radar network is currently limited to some areas in the world. So, with the advent of meteorological satellites in the 1970s, great efforts have been directed to estimating precipitation from satellite images (e.g., TRMM, TMPA, CMORPH, and GSMAP), which cover most of the globe (Table 3 ).

However, the accuracy of remote sensing satellites precipitation may not be desirable and the estimation of precipitation can be improved by blending rain gauge and satellite data [151]. Several statistical merging schemes have been developed for experimental or/and operational use, such as conditional merging [152], Bayesian merging [153], statistical objective analysis [154], data assimilation [137, 155], and double/single optimal estimation [156].

Gottschalck et al. [157] showed that the Climate Prediction Center (CPC) Merged Analysis of Precipitation (CMAP) has the closest agreement with a CPC rain gauge dataset for all seasons except winter, while TRMM overestimated summertime precipitation in the central United States (200$400 \mathrm{~mm}$ ). Chappell et al. [158] evaluated geostatistical methods of blending satellite and gauge data to estimate near real-time daily rainfall for Australia and results showed that the blending considerably reduced the estimation variance. Mitra et al. [159] showed that TRMM merged with gauged station data can significantly improve the estimation of spatial distribution of precipitation of the Indian monsoon region. Ryo et al. [160] showed that the blended precipitation data can improve the hydrological modeling especially the flood modeling in Vietnam.

\section{Summary}

This paper provides a comprehensive review of catchment, regional and global runoff modeling. Continuous surface runoff modeling can be carried out through conceptual rainfall-runoff models, distributed models, and land surface models. Parameterization of hydrological models in ungauged catchments can be done by regionalization, multiple objective model calibration, and regional calibration against observations from multiple catchments. The models can be further improved by incorporating remote sensing vegetation data and remote sensing precipitation data.
There is still considerable room to improve surface runoff prediction from catchments to large regions. In a large region, improving regionalization performance can be attributed to improved catchment characteristics, ensemble of different regionalization approaches, multiple-donor output averaging, or model ensemble, and so forth. Special attention should be paid to use of remote sensing data for multiple objective model calibration and to improving hydrological model structure using remote sensing data since they have great advantages in ungauged catchments or data sparse regions. How to smartly parameterize global land surface models or smartly modify their structure for improving runoff predictions from large regions to globe will be a great challenge for hydrologists and meteorologists in the next couple of decades.

\section{Conflict of Interests}

The authors declare that there is no conflict of interests regarding the publication of this paper.

\section{Acknowledgments}

This research was supported by the National Natural Science Foundation of China (no. 51209152), the Open Fund (SKHL1406) supported by the State Key Laboratory of Hydraulics and Mountain River Engineering, and the CSIRO strategic project (R-7197-1) on global hydrology study.

\section{References}

[1] H. Li, Y. Zhang, J. Vaze, and B. Wang, "Separating effects of vegetation change and climate variability using hydrological modelling and sensitivity-based approaches," Journal of Hydrology, vol. 420-421, pp. 403-418, 2012.

[2] F. Zhao, F. H. S. Chiew, L. Zhang, J. Vaze, J. M. Perraud, and M. Li, "Application of a macroscale hydrologic model to estimate streamflow across Southeast Australia," Journal of Hydrometeorology, vol. 13, no. 4, pp. 1233-1250, 2012.

[3] S. Sorooshian and V. Gupta, "Effective and efficient global optimization for conceptual rainfall-runoff models," Water Resources Research, vol. 28, no. 4, pp. 1015-1031, 1992.

[4] Y. Zhang, F. H. S. Chiew, L. Zhang, and H. Li, "Use of remotely sensed actual evapotranspiration to improve rainfall-runoff modeling in Southeast Australia," Journal of Hydrometeorology, vol. 10, no. 4, pp. 969-980, 2009.

[5] J. Andersen, G. Dybkjaer, K. H. Jensen, J. C. Refsgaard, and K. Rasmussen, "Use of remotely sensed precipitation and leaf area index in a distributed hydrological model," Journal of Hydrology, vol. 264, no. 1-4, pp. 34-50, 2002.

[6] M. Li and Q. Shao, "An improved statistical approach to merge satellite rainfall estimates and raingauge data," Journal of Hydrology, vol. 385, no. 1-4, pp. 51-64, 2010.

[7] H. Madsen, "Automatic calibration of a conceptual rainfallrunoff model using multiple objectives," Journal of Hydrology, vol. 235, no. 3-4, pp. 276-288, 2000.

[8] J. A. Vrugt, H. V. Gupta, L. A. Bastidas, W. Bouten, and S. Sorooshian, "Effective and efficient algorithm for multiobjective optimization of hydrologic models," Water Resources Research, vol. 39, no. 8, p. 1214, 2003. 
[9] R. Willem Vervoort, S. F. Miechels, F. F. van Ogtrop, and J. H. Guillaume, "Remotely sensed evapotranspiration to calibrate a lumped conceptual model: pitfalls and opportunities," Journal of Hydrology, vol. 519, pp. 3223-3236, 2014.

[10] A. Abu El-Nasr, J. G. Arnold, J. Feyen, and J. Berlamont, "Modelling the hydrology of a catchment using a distributed and a semi-distributed model," Hydrological Processes, vol. 19, no. 3, pp. 573-587, 2005.

[11] M. Huang and L. Zhang, "Hydrological responses to conservation practices in a catchment of the Loess Plateau, China," Hydrological Processes, vol. 18, no. 10, pp. 1885-1898, 2004.

[12] Y. Zhang and F. H. S. Chiew, "Relative merits of different methods for runoff predictions in ungauged catchments," Water Resources Research, vol. 45, no. 7, Article ID W07412, 2009.

[13] F. Li, Y. Zhang, Z. Xu et al., "The impact of climate change on runoff in the southeastern Tibetan Plateau," Journal of Hydrology, vol. 505, pp. 188-201, 2013.

[14] A. R. Young, "Stream flow simulation within UK ungauged catchments using a daily rainfall-runoff model," Journal of Hydrology, vol. 320, no. 1-2, pp. 155-172, 2006.

[15] L. Oudin, V. Andréassian, C. Perrin, C. Michel, and N. Le Moine, "Spatial proximity, physical similarity, regression and ungaged catchments: a comparison of regionalization approaches based on 913 French catchments," Water Resources Research, vol. 44, no. 3, Article ID W03413, 2008.

[16] A. K. Mishra and P. Coulibaly, "Developments in hydrometric network design: a review," Reviews of Geophysics, vol. 47, no. 2, Article ID RG2001, 2009.

[17] M. Sivapalan, "Prediction in ungauged basins: a grand challenge for theoretical hydrology," Hydrological Processes, vol. 17, no. 15, pp. 3163-3170, 2003.

[18] M. Hrachowitz, H. H. G. Savenije, G. Blöschl et al., "A decade of Predictions in Ungauged Basins (PUB)-a review," Hydrological Sciences Journal, vol. 58, no. 6, pp. 1198-1255, 2013.

[19] R. Merz and G. Blöschl, "Regionalisation of catchment model parameters," Journal of Hydrology, vol. 287, no. 1-4, pp. 95-123, 2004.

[20] T. Razavi and P. Coulibaly, "Streamflow prediction in ungauged basins: review of regionalization methods," Journal of Hydrologic Engineering, vol. 18, no. 8, pp. 958-975, 2013.

[21] J. Parajka, G. Blöschl, and R. Merz, "Regional calibration of catchment models: potential for ungauged catchments," Water Resources Research, vol. 43, no. 6, Article ID W06406, 2007.

[22] Y. Q. Zhang, N. R. Viney, F. H. S. Chiew, A. I. J. M. Van Dijk, and Y. Y. Liu, "Improving hydrological and vegetation modelling using regional model calibration schemes together with remote sensing data," in Proceedings of the 19th International Congress on Modelling and Simulation (MODSIM '11), pp. 3448-3454, December 2011.

[23] W. Boughton and F. Chiew, Calibrations of the AWBM for Use on Ungauged Catchments, 2004.

[24] C. Perrin, C. Michel, and V. Andréassian, "Improvement of a parsimonious model for streamflow simulation," Journal of Hydrology, vol. 279, no. 1-4, pp. 275-289, 2003.

[25] S. Bergstrom, "The HBV model," in Computer Models of Watershed Hydrology, V. P. Singh, Ed., 1995.

[26] A. D. Feldman, "HEC models for water resources management simulation: theory and experience," Advances in Hydroscience, vol. 12, pp. 297-423, 1981.

[27] N. H. Crawford and R. K. Linsley, Digital Simulation in Hydrology: Stanford Watershed Model IV, Stanford University, Stanford, Calif, USA, 1966.
[28] J. W. Porter and T. A. McMahon, "A model for the simulation of streamflow data from climatic records," Journal of Hydrology, vol. 13, pp. 297-324, 1971.

[29] A. J. Jakeman and G. M. Hornberger, "How much complexity is warranted in a rainfall-runoff model?" Water Resources Research, vol. 29, no. 8, pp. 2637-2649, 1993.

[30] R. J. Burnash, C. Ferreal, R. A. McGuire, and R. L. McGuire, A Generalized Streamflow Simulation System: Conceptual Modeling for Digital Computers, U.S. Department of Commerce, National Weather Service, 1973.

[31] F. H. S. Chiew, M. C. Peel, and A. W. Western, "Application and testing of the simple rainfall-runoff model SIMHYD," in Mathematical Models of Small Watershed Hydrology and Applications, V. P. Singh and D. K. Frevert, Eds., Water Resources Publications, Littleton, Colo, USA, 2002.

[32] N. H. Crawford and R. K. Linsley, The Synthesis of Continuous Streamflow Hydrographs on a Digital Computer, Stanford University, 1962.

[33] M. Sugawawa, I. Watanabe, E. Ozaki, and Y. Katsuyama, Tank Model Programs for Personal Computer and the Way to Use, National Research Center for Disaster Prevention, Tsukuba, Japan, 1961.

[34] Z. Ren-Jun, “The Xinanjiang model applied in China," Journal of Hydrology, vol. 135, no. 1-4, pp. 371-381, 1992.

[35] J. Martinec, "Snowmelt-Runoff Models for stream flow forecasts," Nordic Hydrology, vol. 6, no. 3, pp. 145-154, 1975.

[36] G. Morin, CEQUEAU, INRS-ETE, 2002.

[37] J.-P. Fortin, R. Turcotte, S. Massicotte, R. Moussa, J. Fitzback, and J. P. Villeneuve, "Distributed watershed model compatible with remote sensing and GIS data. I: description of model," Journal of Hydrologic Engineering, vol. 6, no. 2, pp. 91-99, 2001.

[38] A. Calver and W. L. Wood, "The institute of hydrology distributed model," in Computer Models of Watershed Hydrology, V. P. Singh, Ed., pp. 595-626, Water Resources Publications, Highlands Ranch, Colo, USA, 1995.

[39] J. C. Refsgaard and B. Storm, "MIKE SHE," in Computer Models in Watershed Hydrology, V. J. Singh, Ed., Water Resources Publications, Littleton, Colo, USA, 1995.

[40] M. B. Abbott, J. C. Bathurst, J. A. Cunge, P. E. O'Connell, and J. Rasmussen, "An introduction to the European Hydrological System-Systeme Hydrologique Europeen, 'SHE', 2: structure of a physically-based, distributed modelling system," Journal of Hydrology, vol. 87, no. 1-2, pp. 61-77, 1986.

[41] G. W. Kite, “The SLURP model," in Computer Models of Watershed Hydrology, V. P. Singh, Ed., pp. 521-562, Water Resources Publications, 1995.

[42] S. L. Neitsch, J. G. Arnold, J. R. Kiniry, J. R. Willams, and K. W. King, "Soil and Water Assessment Tool Theoretical Documentation," Version 2000, 2000, http://swat.tamu.edu/ documentation/.

[43] L. A. Rossman, Storm Water Management Model User's Manual, EPA/600/R-05/040, U.S. Environmental Protection Agency, Cincinnati, Ohio, 2007.

[44] K. J. Beven and M. J. Kirkby, "A physically based, variable contributing area model of basin hydrology / Un modèle à base physique de zone d'appel variable de l'hydrologie du bassin versant," Hydrological Sciences Bulletin, vol. 24, no. 1, pp. 43-69, 1979.

[45] N. Kouwen, WATFLOOD/SPL9 Hydrological Model \& Flood Forecasting System, University of Waterloo, 2001. 
[46] N. Hanasaki, S. Kanae, and T. Oki, "Global energy and water balance simulation with bucket model for GSWP2," in Proceedings of the 18th Conference on Hydrology and the 15th Symposium on Global Change and Climate Variations, JP4.26, 2004.

[47] E. A. Kowalczyk, Y. P. Wang, R. M. Law, H. L. Davies, J. L. McGregor, and G. Abramowitz, "CSIRO atmosphere biosphere land exchange (CABLE) model for use in climate models and as an offline model," CMAR Research Paper 013, 2006.

[48] R. E. Dickinson, A. Henderson-Sellers, P. J. Kennedy, and M. F. Wilson, "Biosphere-atmosphere transfer scheme (BATS) for the NCAR community climate model," Technical Note TN275+STR, National Center for Atmospheric Research, Boulder, Colo, USA, 1986.

[49] K. W. Oleson, D. M. Lawrence, G. B. Bonan et al., “Technical description of version 4.5 of the Community Land Model (CLM)," NCAR Technical Note NCAR/TN-503+STR, 2013.

[50] G. Y. Niu and Z. L. Yang, “The versatile integrator of surface and atmosphere processes (VISA). Part 2: evaluation of three topography-based runoff schemes," Global and Planetary Change, vol. 38, pp. 191-208, 2003.

[51] P. A. Dirmeyer and F. J. Zeng, "An update to the distribution and treatment of vegetation and soil properties in SSiB," COLA Technical Report 78, 1999.

[52] J. R. Meigh, A. A. McKenzie, and K. J. Sene, "A grid-based approach to water scarcity estimates for eastern and southern Africa," Water Resources Management, vol. 13, no. 2, pp. 85-115, 1999.

[53] N. Hanasaki, S. Kanae, T. Oki et al., "An integrated model for the assessment of global water resources-part 1: model description and input meteorological forcing," Hydrology and Earth System Sciences, vol. 12, no. 4, pp. 1007-1025, 2008.

[54] G. Balsamo, P. Viterbo, A. Beijaars et al., "A revised hydrology for the ECMWF model: verification from field site to terrestrial water storage and impact in the integrated forecast system," Journal of Hydrometeorology, vol. 10, no. 3, pp. 623-643, 2009.

[55] D. M. Mocko and Y. C. Sud, "Refinements to SSiB with an emphasis on snowphysics: evaluation and validation using GSWP and valdai data," Earth Interactions, vol. 5, no. 1, pp. 131, 2001.

[56] P. Etchevers, C. Golaz, and F. Habets, "Simulation of the water budget and the river flows of the Rhone basin from 1981 to 1994," Journal of Hydrology, vol. 244, no. 1-2, pp. 60-85, 2001.

[57] P. M. Cox, R. A. Betts, C. B. Bunton, R. L. H. Essery, P. R. Rowntree, and J. Smith, "The impact of new land surface physics on the GCM simulation of climate and climate sensitivity," Climate Dynamics, vol. 15, no. 3, pp. 183-203, 1999.

[58] P. C. D. Milly and A. B. Shmakin, "Global modeling of land water and energy balances. Part I: the land dynamics (LaD) model," Journal of Hydrometeorology, vol. 3, no. 3, pp. 283-299, 2002.

[59] S. Rost, D. Gerten, A. Bondeau, W. Lucht, J. Rohwer, and S. Schaphoff, "Agricultural green and blue water consumption and its influence on the global water system," Water Resources Research, vol. 44, no. 9, Article ID W09405, 2008.

[60] N. W. Arnell, "A simple water balance model for the simulation of streamflow over a large geographic domain," Journal of Hydrology, vol. 217, no. 3-4, pp. 314-335, 1999.

[61] K. Takata, S. Emori, and T. Watanabe, "Development of the minimal advanced treatments of surface interaction and runoff," Global and Planetary Change, vol. 38, no. 1-2, pp. 209-222, 2003.
[62] R. D. Koster and M. J. Suarez, "The influence of land surface moisture retention on precipitation statistics," Journal of Climate, vol. 9, no. 10, pp. 2551-2567, 1996.

[63] S. Hagemann and L. D. Gates, "Improving a subgrid runoff parameterization scheme for climate models by the use of high resolution data derived from satellite observations," Climate Dynamics, vol. 21, no. 3-4, pp. 349-359, 2003.

[64] F. Chen, K. Mitchell, J. Schaake et al., "Modeling of land surface evaporation by four schemes and comparison with FIFE observations," Journal of Geophysical Research D: Atmospheres, vol. 101, no. 3, pp. 7251-7268, 1996.

[65] A. Ducharne, R. D. Koster, M. J. Suarez, M. Stieglitz, and P. Kumar, "A catchment-based approach to modeling land surface processes in a general circulation model 2. Parameter estimation and model demonstration," Journal of Geophysical Research D: Atmospheres, vol. 105, no. 20, pp. 24823-24838, 2000.

[66] P. de Rosnay and J. Polcher, "Modelling root water uptake in a complex land surface scheme coupled to a GCM," Hydrology and Earth System Sciences, vol. 2, no. 2-3, pp. 239-255, 1998.

[67] K. Tanaka, N. Tadanori, and I. Shuichi, "Land-surface parameterization in the Lake Biwa project," Proceedings of Hydraulic Engineering, vol. 42, pp. 79-84, 1998 (Japanese).

[68] Y. M. Gusev and O. N. Nasonova, "An experience of modelling heat and water exchange at the land surface on a large river basin scale," Journal of Hydrology, vol. 233, no. 1-4, pp. 1-18, 2000.

[69] P. J. Sellers, Y. Mintz, Y. C. Sud, and A. Dalcher, "A simple biosphere model $(\mathrm{SiB})$ for use within general circulation models," Journal of the Atmospheric Sciences, vol. 43, no. 6, pp. 505-531, 1986.

[70] D. P. Lettenmaier, E. F. Wood, and S. J. Burges, "A simple hydrologically based model of land surface water and energy fluxes for general circulation models," Journal of Geophysical Research, vol. 99, no. 7, pp. 14-428, 1994.

[71] Z.-L. Yang and G.-Y. Niu, "The versatile integrator of surface and atmosphere processes part 1. Model description," Global and Planetary Change, vol. 38, no. 1-2, pp. 175-189, 2003.

[72] J. Alcamo, P. Döll, T. Henrichs et al., "Development and testing of the WaterGAP 2 global model of water use and availability," Hydrological Sciences Journal, vol. 48, no. 3, pp. 317-338, 2003.

[73] K. J. Beven, Rainfall-Runoff Modeling-The Primer, Wiley, Chichester, UK, 2001.

[74] I. Haddeland, D. B. Clark, W. Franssen et al., "Multimodel estimate of the global terrestrial water balance: setup and first results," Journal of Hydrometeorology, vol. 12, no. 5, pp. 869-884, 2011.

[75] T. Wagener, "Evaluation of catchment models," Hydrological Processes, vol. 17, no. 16, pp. 3375-3378, 2003.

[76] F. H. S. Chiew, A. J. Pitman, and T. A. McMahon, "Conceptual catchment scale rainfall-runoff models and AGCM landsurface parameterisation schemes," Journal of Hydrology, vol. 179, no. 1-4, pp. 137-157, 1996.

[77] H. Kling and H. Gupta, "On the development of regionalization relationships for lumped watershed models: the impact of ignoring sub-basin scale variability," Journal of Hydrology, vol. 373, no. 3-4, pp. 337-351, 2009.

[78] G. Fleming, Computer Simulation Techniques in Hydrology, Elsevier, New York, NY, USA, 1975.

[79] V. P. Singh, Computer Models of Watershed Hydrology, Water Resources Publications, 1995. 
[80] H. V. Gupta, S. Sorooshian, and P. O. Yapo, “Toward improved calibration of hydrologic models: multiple and noncommensurable measures of information," Water Resources Research, vol. 34, no. 4, pp. 751-763, 1998.

[81] T. Vansteenkiste, M. Tavakoli, V. Ntegeka et al., "Intercomparison of hydrological model structures and calibration approaches in climate scenario impact projections," Journal of Hydrology, vol. 519, pp. 743-755, 2014.

[82] S. Reed, V. Koren, M. Smith, Z. Zhang, F. Moreda, and D.-J. Seo, "Overall distributed model intercomparison project results," Journal of Hydrology, vol. 298, no. 1-4, pp. 27-60, 2004.

[83] T. M. Carpenter and K. P. Georgakakos, "Intercomparison of lumped versus distributed hydrologic model ensemble simulations on operational forecast scales," Journal of Hydrology, vol. 329, no. 1-2, pp. 174-185, 2006.

[84] D. J. Booker and R. A. Woods, "Comparing and combining physically-based and empirically-based approaches for estimating the hydrology of ungauged catchments," Journal of Hydrology, vol. 508, pp. 227-239, 2014.

[85] C. Perrin, C. Michel, and V. Andréassian, "Does a large number of parameters enhance model performance? Comparative assessment of common catchment model structures on 429 catchments," Journal of Hydrology, vol. 242, no. 3-4, pp. 275-301, 2001.

[86] G. B. Bonan, "A land surface model (LSM version 1.0) for ecological, hydrological, and atmospheric studies: technical description and user's guide," NCAR Technical Note NCAR/ TN-417+STR, National Center for Atmospheric Research, 1996.

[87] S. Manabe, "Climate and the ocean circulation I. The atmospheric circulation and the hydrology of the Earth's surface," Monthly Weather Review, vol. 97, no. 11, pp. 739-774, 1969.

[88] R. D. Koster and P. C. D. Milly, "The interplay between transpiration and runoff formulations in land surface schemes used with atmospheric models," Journal of Climate, vol. 10, no. 7, pp. 1578-1591, 1997.

[89] R. Stöckli, P. L. Vidale, A. Boone, and C. Schär, "Impact of scale and aggregation on the terrestrial water exchange: integrating land surface models and rhône catchment observations," Journal of Hydrometeorology, vol. 8, no. 5, pp. 1002-1015, 2007.

[90] E. Widén-Nilsson, S. Halldin, and C.-Y. Xu, "Global waterbalance modelling with WASMOD-M: parameter estimation and regionalisation," Journal of Hydrology, vol. 340, no. 1-2, pp. 105-118, 2007.

[91] S. N. Gosling, R. G. Taylor, N. W. Arnell, and M. C. Todd, "A comparative analysis of projected impacts of climate change on river runoff from global and catchment-scale hydrological models," Hydrology and Earth System Sciences, vol. 15, no. 1, pp. 279-294, 2011.

[92] G. Blöschl and M. Sivapalan, "Scale issues in hydrological modelling: a review," Hydrological Processes, vol. 9, no. 3-4, pp. 251-290, 1995.

[93] J. Samuel, P. Coulibaly, and R. A. Metcalfe, "Estimation of continuous streamflow in ontario ungauged basins: comparison of regionalization methods," Journal of Hydrologic Engineering, vol. 16, no. 5, pp. 447-459, 2011.

[94] S. Stoll and M. Weiler, "Explicit simulations of stream networks to guide hydrological modelling in ungauged basins," Hydrology and Earth System Sciences, vol. 14, no. 8, pp. 1435-1448, 2010.

[95] L. M. Parada and X. Liang, "A novel approach to infer streamflow signals for ungauged basins," Advances in Water Resources, vol. 33, no. 4, pp. 372-386, 2010.
[96] J. Parajka, R. Merz, and G. Blöschl, "A comparison of regionalisation methods for catchment model parameters," Hydrology and Earth System Sciences, vol. 9, no. 3, pp. 157-171, 2005.

[97] H. Li, Y. Zhang, F. H. S. Chiew, and S. Xu, "Predicting runoff in ungauged catchments by using Xinanjiang model with MODIS leaf area index," Journal of Hydrology, vol. 370, no. 1-4, pp. 155$162,2009$.

[98] J. P. C. Reichl, A. W. Western, N. R. McIntyre, and F. H. S. Chiew, "Optimization of a similarity measure for estimating ungauged streamflow," Water Resources Research, vol. 45, no. 10, Article ID W10423, 2009.

[99] L. Samaniego, A. Bárdossy, and R. Kumar, "Streamflow prediction in ungauged catchments using copula-based dissimilarity measures," Water Resources Research, vol. 46, no. 2, Article ID W02506, 2010.

[100] I. Masih, S. Uhlenbrook, S. Maskey, and M. D. Ahmad, "Regionalization of a conceptual rainfall-runoff model based on similarity of the flow duration curve: a case study from the semiarid Karkheh basin, Iran," Journal of Hydrology, vol. 391, no. 1-2, pp. 188-201, 2010.

[101] M. Li, Q. Shao, L. Zhang, and F. H. S. Chiew, "A new regionalization approach and its application to predict flow duration curve in ungauged basins," Journal of Hydrology, vol. 389, no. 1-2, pp. 137-145, 2010.

[102] C. Shu and T. B. M. J. Ouarda, "Improved methods for daily streamflow estimates at ungauged sites," Water Resources Research, vol. 48, no. 2, Article ID W02523, 2012.

[103] N. McIntyre, H. Lee, H. Wheater, A. Young, and T. Wagener, "Ensemble predictions of runoff in ungauged catchments," Water Resources Research, vol. 41, no. 12, Article ID W12434, 2005.

[104] A. L. Kay, D. A. Jones, S. M. Crooks, A. Calver, and N. S. Reynard, "A comparison of three approaches to spatial generalization of rainfall-runoff models," Hydrological Processes, vol. 20, no. 18, pp. 3953-3973, 2006.

[105] F. Li, Y. Zhang, Z. Xu, C. Liu, Y. Zhou, and W. Liu, "Runoff predictions in ungauged catchments in southeast Tibetan Plateau," Journal of Hydrology, vol. 511, pp. 28-38, 2014.

[106] Y. Zhang, J. Vaze, F. H. Chiew, J. Teng, and M. Li, "Predicting hydrological signatures in ungauged catchments using spatial interpolation, index model, and rainfall-runoff modelling," Journal of Hydrology, vol. 517, pp. 936-948, 2014.

[107] K. J. Beven, "Changing ideas in hydrology—the case of physically-based models," Journal of Hydrology, vol. 105, no. 12, pp. 157-172, 1989.

[108] H. V. Gupta, T. Wagener, and Y. Liu, "Reconciling theory with observations: elements of a diagnostic approach to model evaluation," Hydrological Processes, vol. 22, no. 18, pp. 38023813, 2008.

[109] J. Seibert and J. J. McDonnell, "On the dialog between experimentalist and modeler in catchment hydrology: use of soft data for multicriteria model calibration," Water Resources Research, vol. 38, no. 11, pp. 231-2314, 2002.

[110] T. Nester, R. Kirnbauer, J. Parajka, and G. Blöschl, "Evaluating the snow component of a flood forecasting model," Hydrology Research, vol. 43, no. 6, pp. 762-779, 2012.

[111] Y. A. Mohamed, H. H. G. Savenije, W. G. M. Bastiaanssen, and B. J. J. M. van den Hurk, "New lessons on the Sudd hydrology learned from remote sensing and climate modeling," Hydrology and Earth System Sciences, vol. 10, no. 4, pp. 507-518, 2006. 
[112] J. Parajka and G. Blöschl, "Validation of MODIS snow cover images over Austria," Hydrology and Earth System Sciences, vol. 10, no. 5, pp. 679-689, 2006.

[113] H. C. Winsemius, H. H. G. Savenije, and W. G. M. Bastiaanssen, "Constraining model parameters on remotely sensed evaporation: justification for distribution in ungauged basins?" Hydrology and Earth System Sciences, vol. 12, no. 6, pp. 14031413, 2008.

[114] Y. Q. Zhang, F. H. S. Chiew, L. Zhang, R. Leuning, and H. A. Cleugh, "Estimating catchment evaporation and runoff using MODIS leaf area index and the Penman-Monteith equation," Water Resources Research, vol. 44, no. 10, Article ID W10420, 2008.

[115] Y. Q. Zhang, N. R. Viney, F. H. S. Chiew, A. I. J. M. Dijk, and Y. Y. Liu, "Improving hydrological and vegetation modelling using regional model calibration schemes together with remote sensing data," in Proceedings of the 19th International Congress on Modelling and Simulation (MODSIM '11), pp. 12-16, Perth, Australia, 2011.

[116] A. Yatagai, K. Kamiguchi, O. Arakawa, A. Hamada, N. Yasutomi, and A. Kitoh, "APHRODITE: constructing a long-term daily gridded precipitation dataset for Asia based on a dense network of rain gauges," Bulletin of the American Meteorological Society, vol. 93, no. 9, pp. 1401-1415, 2012.

[117] R. Joseph, T. M. Smith, M. R. P. Sapiano, and R. R. Ferraro, "A new high-resolution satellite-derived precipitation dataset for climate studies," Journal of Hydrometeorology, vol. 10, no. 4, pp. 935-952, 2009.

[118] P. A. Dirmeyer, A. J. Dolman, and N. Sato, “The global soil wetness project: a pilot project for global land surface modeling and validation," Bulletin of the American Meteorological Society, vol. 80, pp. 851-878, 1999.

[119] G. P. Weedon, S. Gomes, P. Viterbo et al., "Creation of the WATCH forcing data and its use to assess global and regional reference crop evaporation over land during the twentieth century," Journal of Hydrometeorology, vol. 12, no. 5, pp. 823848, 2011.

[120] G. P. Weedon, G. Balsamo, N. Bellouin, S. Gomes, M. J. Best, and P. Viterbo, "The WFDEI meteorological forcing data set: WATCH Forcing Data methodology applied to ERA-Interim reanalysis data," Water Resources Research, vol. 50, no. 9, pp. 7505-7514, 2014.

[121] P. Xie and P. A. Arkin, "Global precipitation: a 17-year monthly analysis based on gauge observations, satellite estimates, and numerical model outputs," Bulletin of the American Meteorological Society, vol. 78, no. 11, pp. 2539-2558, 1997.

[122] R. J. Joyce, J. E. Janowiak, P. A. Arkin, and P. Xie, "CMORPH: a method that produces global precipitation estimates from passive microwave and infrared data at high spatial and temporal resolution," Journal of Hydrometeorology, vol. 5, no. 3, pp. 487503, 2004.

[123] I. Harris, P. D. Jones, T. J. Osborn, and D. H. Lister, “Updated high-resolution grids of monthly climatic observations-the CRU TS3.10 Dataset," International Journal of Climatology, vol. 34, no. 3, pp. 623-642, 2014.

[124] P. E. Thornton, M. M. Thornton, B. W. Mayer et al., Daymet: Daily Surface Weather Data on a 1-km Grid for North America, Version 2. Data Set, Oak Ridge National Laboratory Distributed Active Archive Center, Oak Ridge, Tenn, USA, 2014, http://daac.ornl.gov/.
[125] D. R. Legates and C. J. Willmott, "Mean seasonal and spatial variability in global surface air temperature," Theoretical and Applied Climatology, vol. 41, no. 1-2, pp. 11-21, 1990.

[126] U. Schneider, A. Becker, P. Finger, A. Meyer-Christoffer, M. Ziese, and B. Rudolf, "GPCC's new land surface precipitation climatology based on quality-controlled in situ data and its role in quantifying the global water cycle," Theoretical and Applied Climatology, vol. 115, no. 1-2, pp. 15-40, 2014.

[127] J. Sheffield, G. Goteti, and E. F. Wood, "Development of a 50year high-resolution global dataset of meteorological forcings for land surface modeling," Journal of Climate, vol. 19, no. 13, pp. 3088-3111, 2006.

[128] R. F. Adler, G. J. Huffman, A. Chang et al., "The version-2 global precipitation climatology project (GPCP) monthly precipitation analysis (1979-present)," Journal of Hydrometeorology, vol. 4, no. 6, pp. 1147-1167, 2003.

[129] A. Andersson, K. Fennig, C. Klepp, S. Bakan, H. Graßl, and J. Schulz, "The hamburg ocean atmosphere parameters and fluxes from satellite data-HOAPS-3," Earth System Science Data, vol. 2, no. 2, pp. 215-234, 2010.

[130] W. G. Large and S. G. Yeager, "The global climatology of an interannually varying air-sea flux data set," Climate Dynamics, vol. 33, no. 2-3, pp. 341-364, 2009.

[131] K. E. Mitchell, D. Lohmann, P. R. Houser et al., "The multiinstitution North American Land Data Assimilation System (NLDAS): utilizing multiple GCIP products and partners in a continental distributed hydrological modeling system," Journal of Geophysical Research, vol. 109, Article ID D07S90, 2004.

[132] M. Rodell, P. R. Houser, U. Jambor et al., "The global land data assimilation system," Bulletin of the American Meteorological Society, vol. 85, no. 3, pp. 381-394, 2004.

[133] S. Sorooshian, K.-L. Hsu, X. Gao, H. V. Gupta, B. Imam, and D. Braithwaite, "Evaluation of PERSIANN system satellitebased estimates of tropical rainfall," Bulletin of the American Meteorological Society, vol. 81, no. 9, pp. 2035-2046, 2000.

[134] M. Chen, P. Xie, J. E. Janowiak, and P. A. Arkin, "Global land precipitation: a 50-yr monthly analysis based on gauge observations," Journal of Hydrometeorology, vol. 3, no. 3, pp. 249-266, 2002.

[135] C. Daly, M. Halbleib, J. I. Smith et al., "Physiographically sensitive mapping of climatological temperature and precipitation across the conterminous United States," International Journal of Climatology, vol. 28, no. 15, pp. 2031-2064, 2008.

[136] R. R. Ferraro, F. Weng, N. C. Grody, and A. Basist, "An eight-year (1987-1994) time series of rainfall, clouds, water vapor, snow cover, and sea ice derived from SSM/I measurements," Bulletin of the American Meteorological Society, vol. 77, no. 5, pp. 891905, 1996.

[137] G. J. Huffman, R. F. Adler, D. T. Bolvin et al., "The TRMM multisatellite precipitation analysis (TMPA): quasi-global, multiyear, combined-sensor precipitation estimates at fine scales," Journal of Hydrometeorology, vol. 8, no. 1, pp. 38-55, 2007.

[138] G. Blöschl, C. Reszler, and J. Komma, "A spatially distributed flash flood forecasting model," Environmental Modelling \& Software, vol. 23, no. 4, pp. 464-478, 2008.

[139] N. K. Tuteja, J. Vaze, J. Teng, and M. Mutendeudzi, "Partitioning the effects of pine plantations and climate variability on runoff from a large catchment in southeastern Australia," Water Resources Research, vol. 43, no. 8, Article ID W08415, 2007.

[140] O. Yildiz and A. P. Barros, "Elucidating vegetation controls on the hydroclimatology of a mid-latitude basin," Journal of Hydrology, vol. 333, no. 2-4, pp. 431-448, 2007. 
[141] N. K. Tuteja, J. Vaze, J. Teng, and M. Mutendeudzi, "Partitioning the effects of pine plantations and climate variability on runoff from a large catchment in southeastern Australia," Water Resources Research, vol. 43, no. 8, Article ID W08415, 2007.

[142] M. Fang and W. Huang, "Tracking the Indonesian forest fire using NOAA/AVHRR images," International Journal of Remote Sensing, vol. 19, no. 3, pp. 387-390, 1998.

[143] M. D. M. Islam and K. Sado, "Development of flood hazard maps of Bangladesh using NOAA-AVHRR images with GIS," Hydrological Sciences Journal, vol. 45, no. 3, pp. 337-355, 2000.

[144] R. Ranzi, G. Grossi, and B. Bacchi, “Ten years of monitoring areal snowpack in the Southern Alps using NOAA-AVHRR imagery, ground measurements and hydrological data," Hydrological Processes, vol. 13, no. 12-13, pp. 2079-2095, 1999.

[145] L. Oudin, V. Andréassian, J. Lerat, and C. Michel, "Has land cover a significant impact on mean annual streamflow? An international assessment using 1508 catchments," Journal of Hydrology, vol. 357, no. 3-4, pp. 303-316, 2008.

[146] X. Liang and Z. Xie, "A new surface runoff parameterization with subgrid-scale soil heterogeneity for land surface models," Advances in Water Resources, vol. 24, no. 9-10, pp. 1173-1193, 2001.

[147] A. J. Pitman, A. G. Slater, C. E. Desborough, and M. Zhao, "Uncertainty in the simulation of runoff due to the parameterization of frozen soil moisture using the Global Soil Wetness Project methodology," Journal of Geophysical Research D: Atmospheres, vol. 104, no. 14, pp. 16879-16888, 1999.

[148] V. Haverd and M. Cuntz, "Soil-Litter-Iso: a one-dimensional model for coupled transport of heat, water and stable isotopes in soil with a litter layer and root extraction," Journal of Hydrology, vol. 388, no. 3-4, pp. 438-455, 2010.

[149] H. I. Choi and X.-Z. Liang, "Improved terrestrial hydrologic representation in mesoscale land surface models," Journal of Hydrometeorology, vol. 11, no. 3, pp. 797-809, 2010.

[150] W. F. Krajewski, G. Villarini, and J. A. Smith, "Radar-rainfall uncertainties: where are we after thirty years of effort," Bulletin of the American Meteorological Society, vol. 91, no. 1, pp. 87-94, 2010.

[151] R. J. Moore, S. J. Cole, and A. J. Illingworth, Weather Radar and Hydrology, IAHS Publication 351, IAHS Press, Wallingford, Conn, USA, 2012.

[152] U. Ehret, Rainfall and flood nowcasting in small catchments using weather radar [Ph.D. thesis], University of Stuttgart, 2002.

[153] E. Todini, "A Bayesian technique for conditioning radar precipitation estimates to rain-gauge measurements," Hydrology and Earth System Sciences, vol. 5, no. 2, pp. 187-199, 2001.

[154] A. J. Pereira Filho, "Integrating gauge, radar and satellite rainfall," in Proceedings of the 2nd International Precipitation Working Group Workshop, 2004.

[155] D. A. Vila, L. G. G. De Goncalves, D. L. Toll, and J. R. Rozante, "Statistical evaluation of combined daily gauge observations and rainfall satellite estimates over continental South America," Journal of Hydrometeorology, vol. 10, no. 2, pp. 533-543, 2009.

[156] D.-J. Seo, "Real-time estimation of rainfall fields using rain gage data under fractional coverage conditions," Journal of Hydrology, vol. 208, no. 1-2, pp. 25-36, 1998.

[157] J. Gottschalck, J. Meng, M. Rodell, and P. Houser, "Analysis of multiple precipitation products and preliminary assessment of their impact on global land data assimilation system land surface states," Journal of Hydrometeorology, vol. 6, no. 5, pp. 573-598, 2005.
[158] A. Chappell, L. H. Renzullo, T. J. Raupach, and M. Haylock, "Evaluating geostatistical methods of blending satellite and gauge data to estimate near real-time daily rainfall for Australia," Journal of Hydrology, vol. 493, pp. 105-114, 2013.

[159] A. K. Mitra, I. M. Momin, E. N. Rajagopal, S. Basu, M. N. Rajeevan, and T. N. Krishnamurti, "Gridded daily Indian monsoon rainfall for 14 seasons: merged TRMM and IMD gauge analyzed values," Journal of Earth System Science, vol. 122, no. 5, pp. 1173-1182, 2013.

[160] M. Ryo, O. C. S. Valeriano, S. Kanae, and T. D. Ngoc, “Temporal downscaling of daily gauged precipitation by application of a satellite product for flood simulation in a poorly gauged basin and its evaluation with multiple regression analysis," Journal of Hydrometeorology, vol. 15, no. 2, pp. 563-580, 2014. 

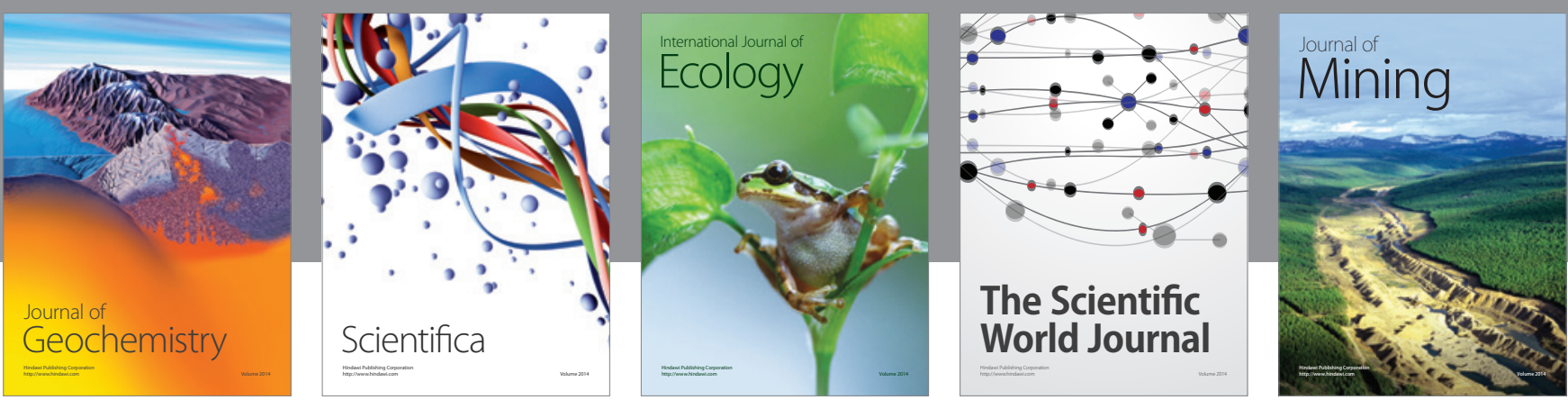

The Scientific World Journal
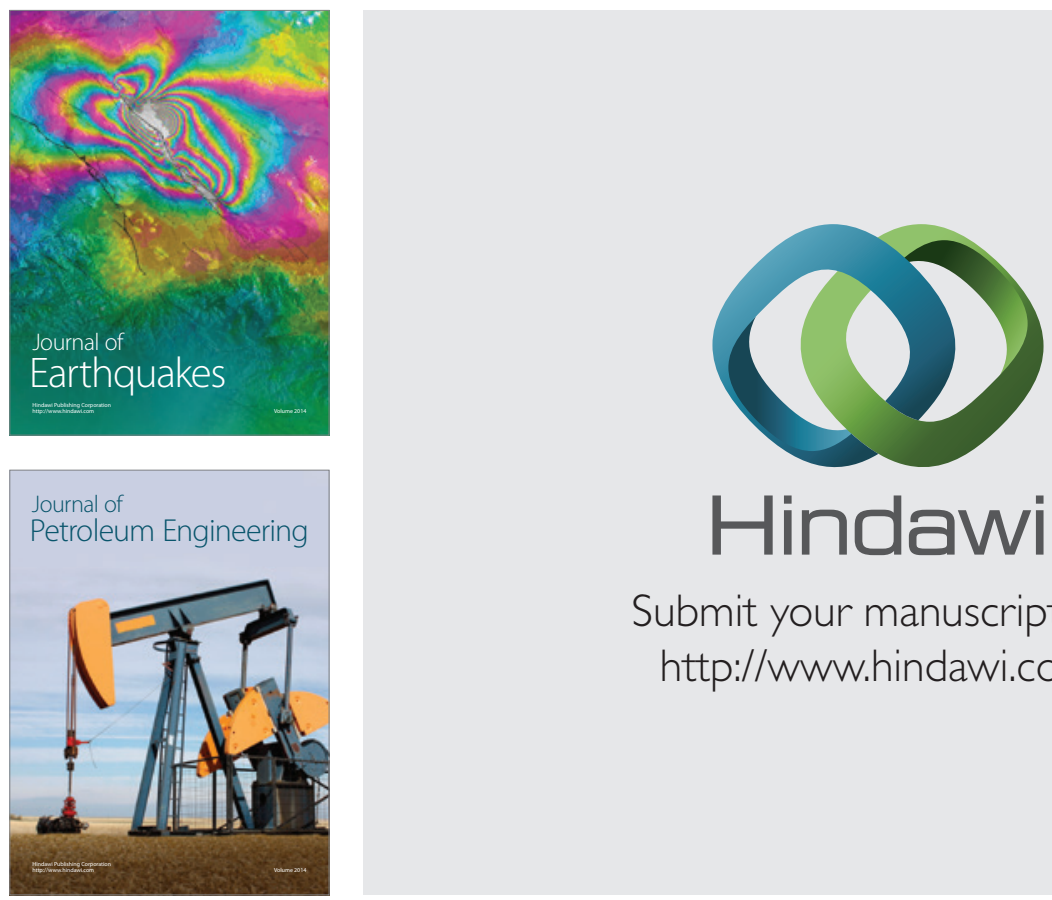

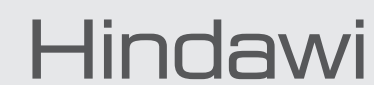

Submit your manuscripts at

http://www.hindawi.com
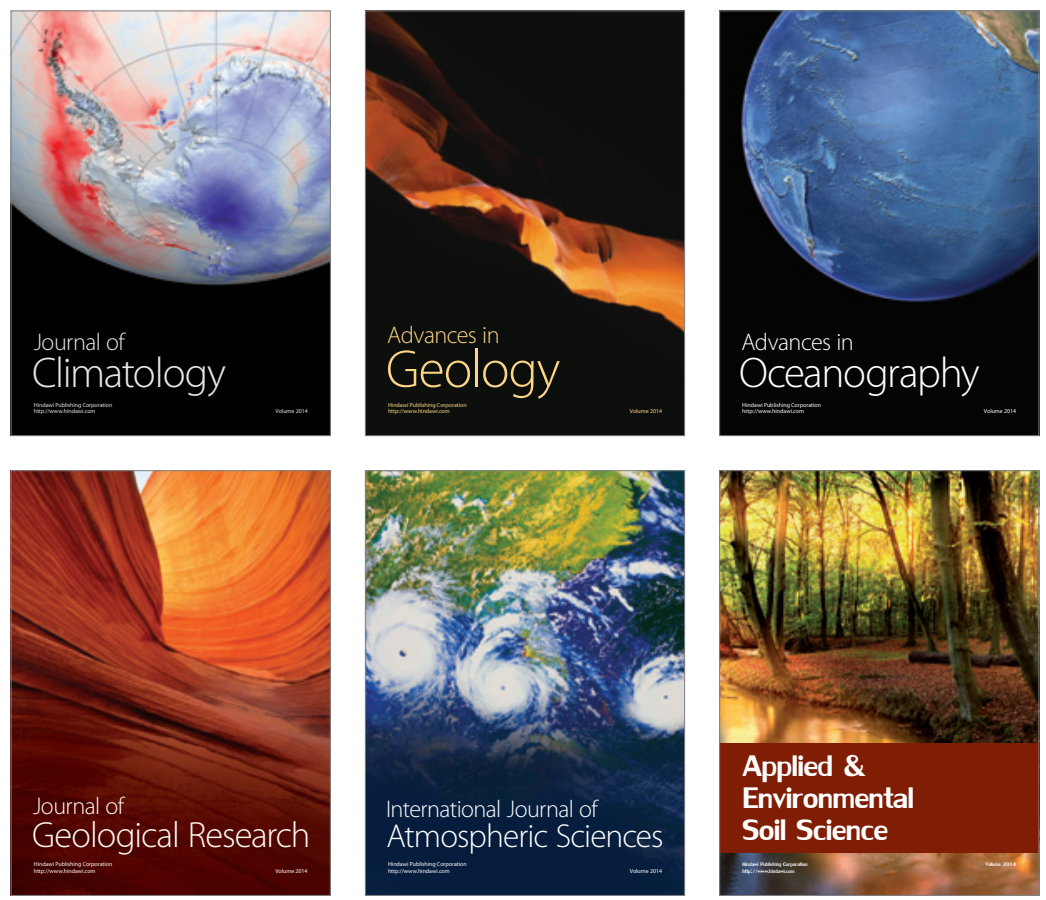
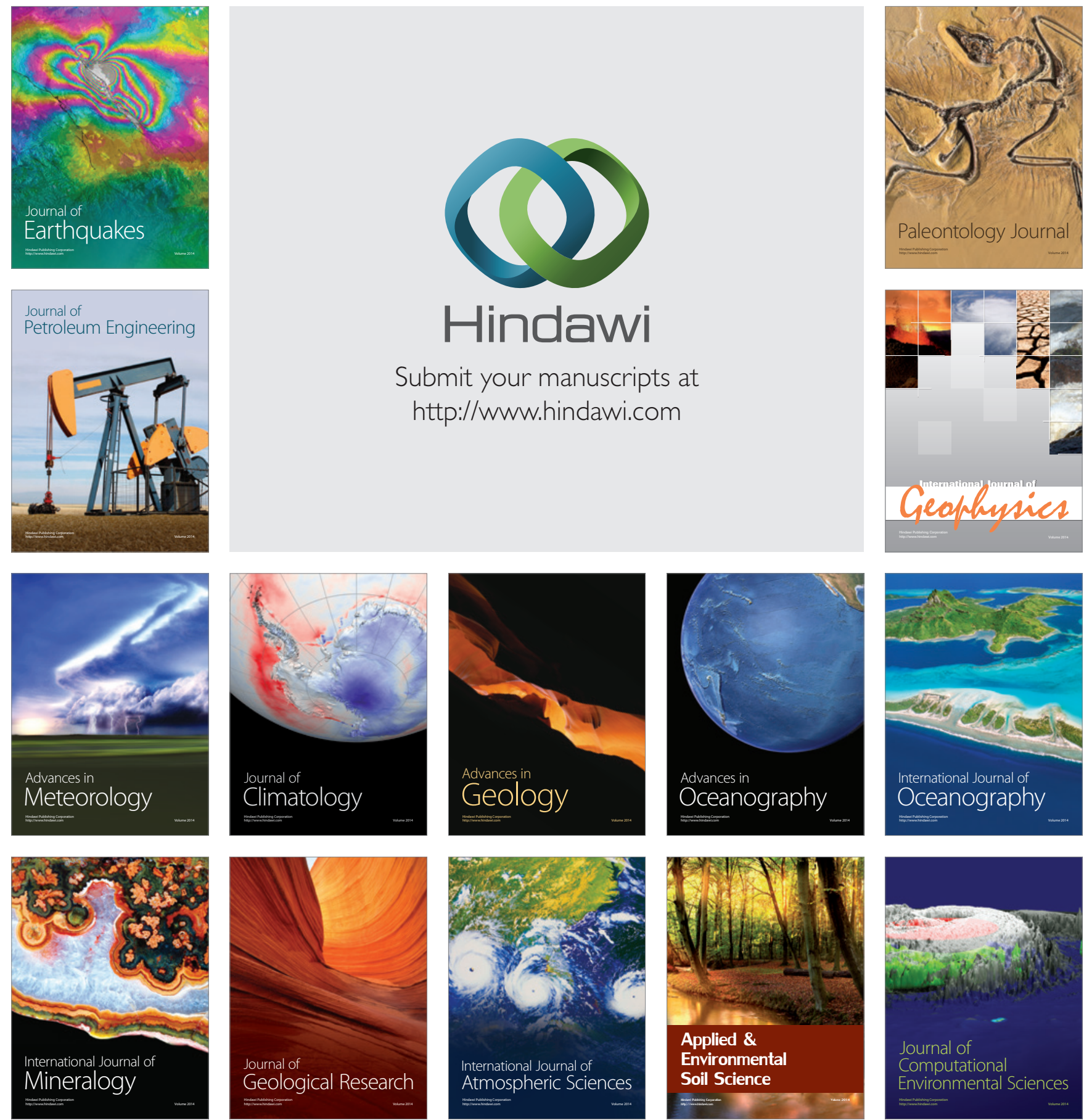